\title{
Helse er et fellesskapsansvar
}

\author{
Det grunnleggende utgangspunktet for Arbeiderpartiet er at helse- og omsorgspolitikk er et fellesskaps- \\ ansvar. Hver og en har ansvar for egen helse. Som fellesskap tar vi ansvar for alles helse.
}

\begin{abstract}
Moderne helsepolitikk handler om å finne riktig balanse mellom å legge til rette for alles rett og mulighet til å ta gode valg for egen helse og å tilby den beste helsehjelp når behovet melder seg, uavhengig av inntekt eller sosial bakgrunn. Nordmenn har god helse. Vi er kommet langt i å utvikle et avansert helsevesen. Men vi møter nye behov og nye muligheter. Derfor vil Arbeiderpartiet investere $\mathrm{i}$ vårt helsevesen fremfor å love titalls milliarder i skattelette.

Vi vil satse på fellesskapets sykehus og primærhelsetjeneste og videreutvikle samhandlingsreformen. Vi vil styrke samfunnets evne til å prioritere slik at ressursene vi bruker, gir mest mulig rettferdig tilgang til best mulig helsetjenester. Vi vil prioritere utvikling av fellesskapets sykehus og private med avtale fremfor å ta av sykehusrammen for å finansiere oppstart av kommersielle sykehustilbud.
\end{abstract}

\section{Mobilisering for folkehelse og forebygging}

Arbeiderpartiets viktigste helsepolitiske mål for bedre fysisk og psykisk helse er å styrke samfunnets evne til å forebygge sykdom for å forhindre at folk kommer på sykehus. Derfor trenger vi en bred samfunnsmobilisering for folkehelse og forebygging. Vi må tenke helse i alle sektorer. Kommunene har et lovpålagt ansvar for folkehelsetiltak, og vi vil styrke kommunehelsetjenestens kapasitet til forebygging og tidlig innsats.

Befolkningsutviklingen vil gi oss langt flere eldre enn i dag. Måten vi lever på gjør oss utsatt for livsstilssykdommer. Dette gir utfordringer i de kommende årene. Vi møter en sykdomsbyrde som er en konsekvens av stillesitting, tobakk, alkohol og usunt kosthold. Vi ser også at flere blir sykmeldt som følge av psykiske lidelser. Flere får kreft, diabetes og kronisk obstruktiv lungesykdom (kols).

Arbeiderpartiet satser på forebyggende arbeid $\mathrm{i}$ helsetjenesten - blant annet gjennom å styrke helsestasjoner og skolehelsetjeneste. Vi skal forebygge forskjeller gjennom å verne om gode fellesskapsløsninger som full barnehagedekning og en skole for alle.
Arbeiderpartiet vil styrke tilbudet nær den enkelte. Mangfold blir kjennetegnet på de nye eldre. De som trenger hjelp og omsorg, skal få det tilpasset egne behov, fra tjenester som gjør det mulig å leve lenger i egen bolig til heldøgnsomsorg og styrket demensomsorg.

Vi skal rekruttere flere fastleger, flere avtalespesialister, flere som kan bistå med

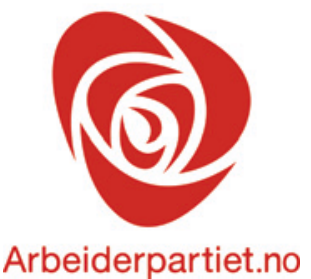

hverdagsrehabilitering i kommunene, og som skal hjelpe mennesker til tidlig behandling og et godt og trygt legevakttilbud.

\section{Sterkere fellesskapssykehus}

Ansatte ved norske sykehus leverer resultater både de og samfunnet kan være stolte av.

Arbeiderpartiet vil møte utfordringer for norske sykehus ved å investere mer og organisere bedre, ikke ved å overføre ressurser til kommersielle sykehus. Vi erkjenner at oppgavene i sykehushverdagen er mange og sammensatte og at arbeidet er hektisk. Det er behov for nye investeringer i bygninger, medisinskteknisk utstyr og moderne IKTløsninger som kan bidra til at de ansattes kompetanse og innsats kommer bedre til sin rett for hovedpersonen: pasienten. Vi prioriterer innsats for bedre ledelse og bedre oppgavefordeling mellom ansatte i sykehus. Utvidet åpningstid ved sykehusene vil bidra til å utnytte ressursene bedre slik at flere kan få utredning og behandling.

Høyre og Frp foreslår en ny form for privatisering av sykehustjenester som Arbeiderpartiet vil advare mot. Mens de offentlige sykehusene må prioritere hardt hver eneste dag, vil forslaget til Høyre og Frp nærmest bety et frislipp av kommersielle aktører som skal kunne sende regningen til det offentlige. Det vil svekke sykehusenes økonomi, det vil etterlate flere av de sammensatte lidelsene i sykehusene, mens flere rutineoppgaver går over til private klinikker. Det vil splitte sårbare fagmiljøer og føre til økt byråkratisering og sentralisering, og bety mindre helse igjen for skattepengene og mer penger til kommersielle tilbydere. Prioriteringene i helsevesenet flyttes bort fra fellesskapet og over til det kommersielle markedet.

Vårt svar er å satse på fellesskapenes sykehus. På åtte år har vi økt bevilgningene til sykehusene med 12 milliarder. Vi har gått fra milliarder i underskudd til økonomisk balanse i alle helseregioner.

Derfor er tiden inne for å gjøre det enklere og mer forutsigbart å planlegge nye sykehus gjennom å utvide rammene for nye investeringslån fra $50 \%$ til $70 \%$, og å utvide nedbetalingstiden på lån fra 20 til 25 år. Med vilje til å bevilge penger til slike investeringer over statsbudsjettet vil sykehusene komme raskere i gang med viktige investeringer til nybygg, medisinskteknisk utstyr og IKT uten å måtte redusere på driften.

Kvalitetsreform skal prege nye satsinger der pasientens rett til god og rett informasjon, veiledning og trygghet skal stå i sentrum. Vi skal forenkle og avskaffe byråkrati, krav og rapportering for å frigjøre ressurser til god behandling.

Vi lover ikke skattekutt eller at de offentlige sykehusene skal finansiere private klinikker uten avtale. Vi vil bruke pengene på å styrke fellesskapets sykehus og arbeide nært med de ansattes organisasjoner for å gjøre norske helsetjenester enda bedre.

\section{Jonas Gahr Støre}

post@arbeiderpartiet.no

Jonas Gahr Støre (f. 1960) er Helse- og omsorgsminister siden september 2012 og stortingspolitiker for Arbeiderpartiet.

Mottatt 26.6.2013 og godkjent 27.6.2013. Medisinsk redaktør Hanne Støre Valeur. 